\title{
Proximate and Ultimate Charaterization of Coal Samples from Southwestern Part of Ethiopia.
}

\author{
N. Rao Cheepurupalli, B. Anuradha
}

\begin{abstract}
This study aimed to characterize the coal in terms of proximate and ultimate analyses. The analytical assessment of properties such as volatile matter, moisture, fixed carbon, and ash content are very important to know the quality of the coal. The proximate analysis results shows that the moisture content varies from 13.4 to $22.6 \mathrm{wt} \%$, the fixed carbon varies from 26.7 and 38 $w t \%$, the ash content varies from 11.9 to $25.7 w t \%$, the volatile matter varies from 23.8 to $36.5 \mathrm{iwt} \%$. The analytical results show that the Carbon content varies from 48.60 to $70.68 \mathrm{wt} \%$, Oxygen content varies from 42.29 to $57.38 \mathrm{wt} \%$, the hydrogen content ranges from 4.43 to $5.28 \mathrm{wt} \%$, the sulphur varies from 1.35 toi3.04 $w t \%$, the Nitrogen content varies from 1.86 to $2.34 w t \%$. Proximate analysis and calorific data show that Ethiopian coal is in the soft coal series (lignite to bituminous coal) and is genetically classified as humic, sapropelic and mixed coal. The present study helps to characterize the coal type and also highlights the importance of chemical parameters in characterizing the coal besides, tracing the depositional environment and also helps to the economical evolutions of the deposit.
\end{abstract}

Keywords: Coal, Proximate analysis, Ultimate analysis and Ethiopia.

\section{INTRODUCTION}

Coal is a hard, brittle, combustible sedimentary rock. It consists predominantly of elemental carbon. It is a non-renewable source of energy because it takes millions of years to form. Geological studies have proved that coal originated from the decay of trees bushes, ferns, mosses, vines, and other forms of plants and conversion of this plant to coal occurs due to the prolonged action of bacteria, fungi, temperature and pressure. Each coal deposit has formed from plant components as well as regional, depositional and paleo-environmental factors that result in the specification of predictable end products for a specific set of biological, chemical and physical conditions that provided an environment in which minerals could be formed. The mineral matter in coal affects various aspects of coal mining and preparation. These inorganic minerals present in the coal are primarily responsible for various technological, ndustrial and environmental problems related to the use of coal. The

Revised Manuscript Received on December 30, 2019.

* Correspondence Author

*N. Rao Cheepurupalli, Department of Mineral Processing Engineering, School of Mines, Aksum University, Tigray, Ethiopia.

E-mail: nraocheepurupalli@gmail.com

B. Anuradha, Department of Chemical, Geological survey of India, Hyderabad, India. E-mail: annnudin@gmail.com

(C) The Authors. Published by Blue Eyes Intelligence Engineering and Sciences Publication (BEIESP). This is an open access article under the CC BY-NC-ND license (http://creativecommons.org/licenses/by-nc-nd/4.0/) composition can be interpreted on the basis of the type, properties, quality and genesis of coal [1]. Each type of coal has a specific set of physical parameters, which are mainly controlled by volatile matter, moisture, ash content and carbon content evaluated as part of a proximate analysis. Coal is characterized by four main types: lignite, bituminous coal, anthracite and graphite. Coal is an organic rock mainly enriched with carbon (C), with a low concentration of hydrogen $(\mathrm{H})$, oxygen $(\mathrm{O})$, sulfur $(\mathrm{S})$ and nitrogen $(\mathrm{N})$, as well as with several inorganic components(minerals) and water. The ultimate analysis $s$ the chemical approach to characterize coal based on the amount of major chemical elements present, such as carbon, hydrogen, nitrogen, oxygen and sulfur.

Ethiopia is endowed with many mineral resources. Coal is one of these resources. Exploration of coal deposits in Ethiopia began around the 1940s. EMDE reported the appearance of $4 \mathrm{~m}$ thick coal in the Yayu Basin [1]. Review of coal resource estimates in the Yayu area was carried out by many researchers [2]. Today, along with growing global technology, the need for alternative energy sources is less of a problem to ensure this demand. Therefore, coal is one of the best alternatives, because it has many applications in various industry sectors, including household and agricultural use. Although coal has such advantages, ash produced in coal causes three threats to the environment: air, water and earth (soil) and destroys the aesthetics of this place. That is why environmentally friendly maintenance is the most mportant need today. For a proper and better utilization of coal in all the sectors, coal should be characterized in terms of proximate, ultimate and colorific values. The present study aims to utlize proximate and ultimate analysis for the characterization the Yayu coal.

\section{A. Location}

The Yayu coal field is located in the province of llubabor, which is located in southwestern Ethiopia. The exploration project area is around $10 \mathrm{~km}^{2}$. The present study area is part of the Wittete block in the Yayu coal deposit (Fig. 1).

\section{B. Geology}

The area consists of neoproterozoic basement rocks at the base and covered with tertiary and sedimentary volcanic rocks containing coal (Fig. 2). Volcanic rocks are divided into two, upper and lower volcanic rocks by age, and geochemical varieties stratigraphic configuration [4]. Upper volcanics include different varieties basalts such as aphanitic basalt, porphyritic basalt, vesicular basalt, amygdaloidal basalt and tuffs. Sedimentary rocks are located between the upper and lower volcanic zone and are formed by coal shales, oil shales, sandstones, shales, clays and coal.

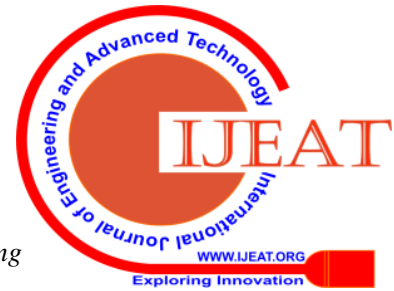


There are 9 coal seams in coal bearing strata; whose name are coal seam 1, 2, 3, 4, 5, 6, 7, 8 and 9 from top to bottom. There is no carbon in the lithological part of the lower sediment. The lithological section of the middle sediment is the main section containing carbon, which includes coal seam 1, 2, 3, $4,5,6$ and 7 , and coal seam 4, 5 and 6 are feasible coal seams in the research district, and coal seams 7 and 3 are sporadic coal seams.

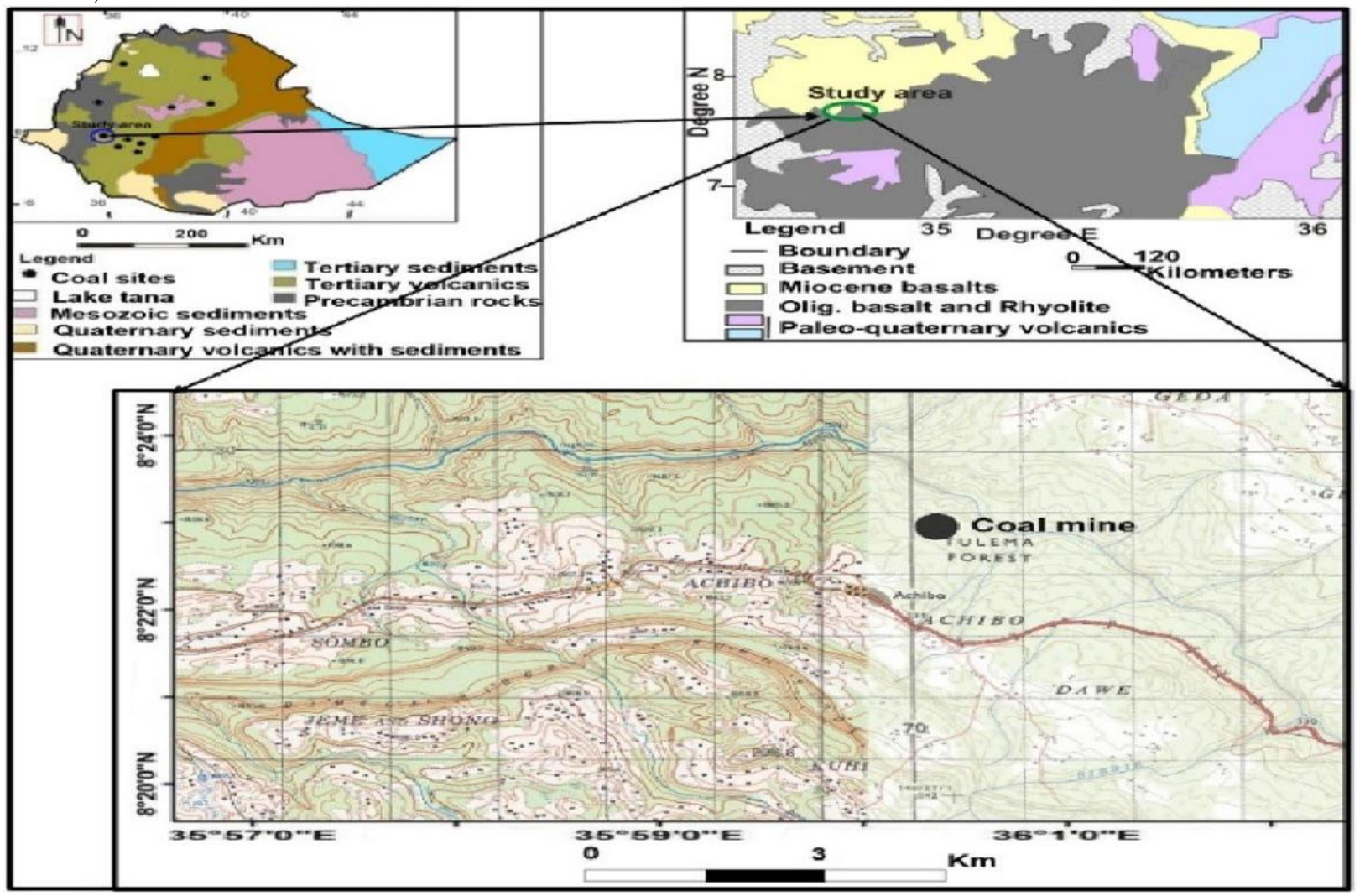

Fig. 1. Location map of the study area with reference to (A) coal map of Ethiopia (B) Regional geological map of southwestern Ethiopia (C) study area. [3].

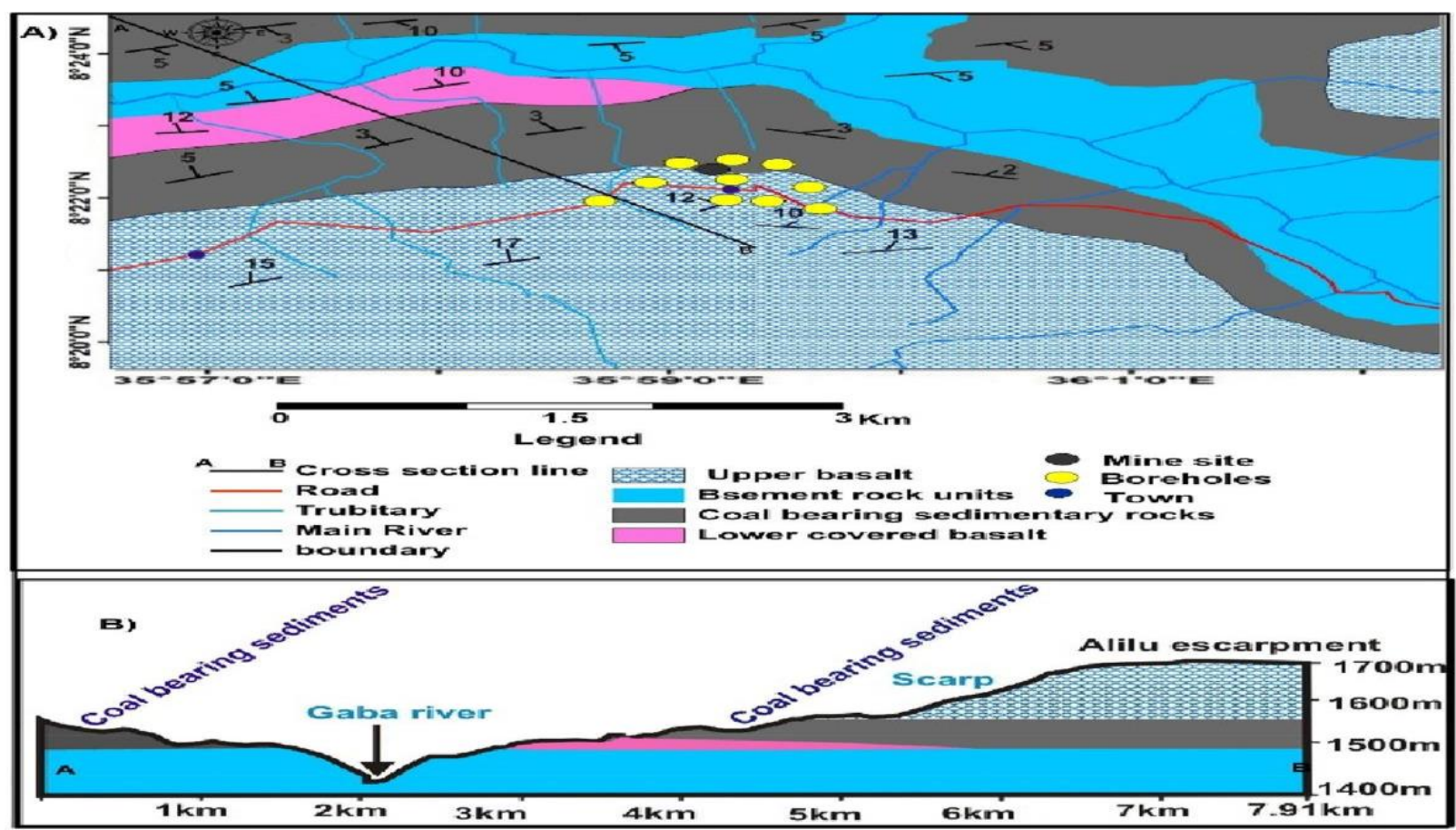

Fig. 2 (A) Geological map (B) cross section profile along the line A-B of the study area [4].

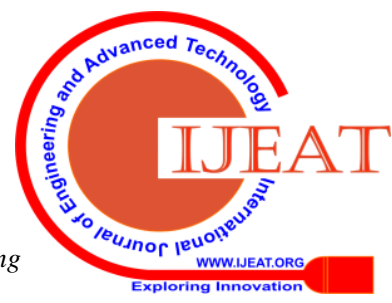




\section{MATERIALS AND METHODS}

\section{A. Sample Collection}

Total 8 nos. coal samples were taken from Yayu Woreda, such as Achibo, and Sombo was selected depending on the presence of coal and previously selected. About $500 \mathrm{~g}$ of samples were collected in an air tight aluminum container, and information such as depth, coal seam and geographical coordinates was recorded separately. Samples for proximate, ultimate and chemical analyses, were pulverized to a mesh size $<200$ and dried for 12 hours in a desiccator.

\section{B. Proximate Analysis}

For proximate analysis,i.e. for the determination of moisture content, volatile matter, moisture, ash content and fixed carbon laid down in Indian Standard IS: 1350 (Part- I) -1984 was followed.

\section{Determination of Moisture Content (M)}

$1 \mathrm{~g}$ of finely pulverized $-212 \mu$ size air-dried coal sample is weighed into a silica crucible and then heated within an electric hot air oven, at $110^{\circ} \mathrm{C}$, for $1.5 \mathrm{~h}$. The crucible with sample was then taken out, cooled in desiccators for 15 minutes and weighed. The loss in weight on percentage basis was taken as the moisture of the sample. The calculation is done as per the following.

$$
\text { M C }(\%)=(\mathrm{Y}-\mathrm{Z} / \mathrm{Y}-\mathrm{X}) \times 100
$$

$\mathrm{Y}=$ weight of crucible + coal sample before heating, $(\mathrm{g})$

$\mathrm{Z}=$ weight of crucible + coal sample after heating, (g)

$\mathrm{Y}-\mathrm{X}=$ weight of coal sample, $(\mathrm{g})$

$\mathrm{Y}-\mathrm{Z}=$ weight of moisture, $(\mathrm{g})$

\section{Determination of Volatile Matter (Vm)}

For determining the volatile matter, a special volatile matter silica crucible (38mm height, $25 \mathrm{~mm}$ external diameter and $22 \mathrm{~mm}$ internal diameter) was used. Initially, the empty silica crucible along with the lid uncovered was heated at $800^{\circ} \mathrm{C}$ for $1 \mathrm{~h}$ in a muffle furnace, cooled to room temperature and then weighed. Exactly, 1g of coal was weighed into the crucible, placed inside the muffle furnace at $925^{\circ} \mathrm{C}$ with the lid covering the crucible, for 7 minutes. Subsequently, the crucible was removed, initially cooled in air followed by that in desiccators and weighed again.

$$
\mathrm{VM}(\%)=(\mathrm{Y}-\mathrm{Z} / \mathrm{Y}-\mathrm{X}) \times 100-\mathrm{M} \%
$$

Where

$\mathrm{X}$ = weight of empty crucible, $(\mathrm{g})$

$\mathrm{Y}=$ weight of crucible + coal sample before heating, (g)

$\mathrm{Z}$ = weight of crucible + coal sample after heating, (g)

$\mathrm{Y}-\mathrm{X}=$ weight of coal sample, $(\mathrm{g})$

$\mathrm{Y}-\mathrm{Z}=$ weight of volatile matter + moisture, $(\mathrm{g})$

\section{Determination of Ash Content (A)}

An empty silica crucible was first heated in a muffle furnace for $1 \mathrm{~h}$, taken out, cooled to room temperature and weigh. Exactly $1 \mathrm{~g}$ of coal sample was weighed into the crucible and heated in a muffle furnace at $450^{\circ} \mathrm{C}$ for 30 minutes. Then the temperature of the furnace was raised to $850^{\circ} \mathrm{C}$ and heating continued for another hour. Subsequently, the crucible was taken out, placed in desiccators and weighed. The residue on percentage basis was reported as ash.

Where,

$$
\text { Ash }(\%)=(Z-X / Y-X) \times 100
$$

$\mathrm{X}=$ weight of empty crucible (g)

$\mathrm{Y}=$ weight of coal samplei+ crucible $(\mathrm{g})$ before heating

$\mathrm{Z}=$ weight of coal sample + crucible $(\mathrm{g})$ after heating

\section{Determination of Fixed Carbon (FC)}

Fixed carbon is determined on air dried basis by subtracting the sum of all the above parameters from 100 .

$$
\mathrm{FC}=100-(\mathrm{M}+\mathrm{VM}+\mathrm{A})
$$

Where,

$\mathrm{M}=$ Moisture (\%)

$\mathrm{VM}=$ Volatile Matter $(\%)$

$\mathrm{A}=$ Ash content of coal. (\%)

\section{Ultimate Analysis}

The Ultimate analysis of coal is used to determination of carbon and hydrogen as gaseous products for complete combustion, determination of sulfur, nitrogen and ash in the whole material and estimation of the oxygen difference. The standard method is explained in (IS: 1350, part II-2000), as well as from the reference [5]. The amount of heat generated during the combustion of a unit of weight of a coal sample is defined as calorific value. Coal calorific values and their characteristics were determined according to IS: 1350-1974, 1975 in a bomb calorimeter.

\section{RESULTS AND DISCUSSION}

\section{A. Proximate Analysis}

The results of proximate analysis for moisture, volatile matter, fixed carbon, and ash are given in Table 1.

Table-I : Descriptive statistics of proximate analysis of Yayu coals samples

\begin{tabular}{|c|c|c|c|c|}
\hline & Moisture & Ash & FixedCarbon & $\begin{array}{c}\text { Volatile } \\
\text { matter }\end{array}$ \\
\hline Minimum & 13.4 & 11.9 & 26.7 & 23.8 \\
\hline Maximum & 22.6 & 25.7 & 38 & 36.5 \\
\hline Mean & 16.725 & 21.46 & 34.215 & 27.55 \\
\hline Median & 16.1 & 23.6 & 34.95 & 25.55 \\
\hline stdev & 3.00 & 5.13 & 3.28 & 4.39 \\
\hline
\end{tabular}

\section{Moisture (M)}

Moisture is an mportant carbon factor because all coals are mined wet. Groundwater and other extraneous moisture, known as random moisture, evaporates easily, while the moisture in the coal is inherent moisture that is quantified. Basically, the moisture content of the coals ranges from $5 \%$ to almost $70 \%$, which is an undesirable component because it reduces the calorific value and ncreases the weight of transport costs. The fluid matter of coal comprises moisture, gas, and gas-liquid inclusions associated with both solid organic matter (OM) and inorganic matter (IM) $[8,7,6]$. The increased content of this physically and chemically adsorbed water is characteristic for the lower range coals, while the reduced values of this parameter are typical for the higher range coals [9]. [10]. In this study, coal samples with moisture content range from 13.4 to $22.6 \%$ by weight and arithmetic mean $16.72 \%$ by weight, which indicates the existence of lignite and partially higher order coal. 


\section{Fixed Carbon (FC)}

The fixed carbon content of coal is the carbon found in the material remaining after the expulsion of volatile materials. This differs from the final carbon content in carbon because some of the carbon is lost in volatile hydrocarbons. The fixed carbon content of coal, excluding moisture and ash, is from $50 \%$ to about $98 \%$. The fixed carbon values depend largely on the $\mathrm{C}$ and $\mathrm{OM}$ values in the coal. It is well known that the FC content increases with the advance of the coal rank [6]. The FC content in the samples in the study is 26.7 to $38 \%$ by weight, with an arithmetic mean of $34.21 \%$ by weight.

\section{Ash Content (AC)}

The ash content of coal is a non-flammable residue that remains after burning coal, which represents the mineral matter after removal of carbon, oxygen, sulfur and water during combustion. which indicates the quality of the coal. These results show that bulk ash yield alone is a poor informative characteristic of coal if origin, composition and abundance are not considered a correlation of ash yield as relatively contradictory [11]. The ash content of the samples ranges from 11.9 to $25.7 \%$ by weight, and the arithmetic mean $21.6 \%$ by weight. High ash yield is usually characterized by a relatively large supply of detritious materials in the swamps; authigenic minerals dominate mainly at low ash content (8-10\%), while the proportion of detritic minerals increases [12], and the concentration of organically bound elements decreases [13] at higher ash yields. These observations, however, seem to concern mainly higher-rank coal, because lignite with high ash content (24-49\%), which is abundant in moisture, autogenic mineralization, calcite, pyrite and gypsum as well as Ca and S organically bound are common [11]. The latest observation also agrees that some low-carbon $(<10 \%)$ ashes contain mainly autogenic and biogenic inorganic substances, while those with higher ash yields ( $>10 \%)$ show simultaneous inorganic detritic and autogenic enrichment [6]

\section{Volatile Matter (VM)}

Volatile matter (VM) in coal refers to the components of coal, with the exception of moisture, which are released at high temperature in the absence of air, which is generally a mixture of short and long chain hydrocarbons, aromatic hydrocarbons and some sulfur. The VM content is measured in the absence of moisture and ashes ranging between $2 \%$ and approximately 50\%. The higher VM content is more characteristic of low-rank coals, while the decreased value is more typical of higher-rank coals in Table 1 and [10]. The high performance of $\mathrm{VM}$ is also indicative of enrichment in liptinite, hydrocarbons, $\mathrm{CO}, \mathrm{CO}_{2}$ and chemically combined water, and for depletion of inertinite [14],[15]. The volatile carbon content in the study area samples varies from 23.8 and $36.5 \%$ by weight with an arithmetic mean of $27.55 \%$ by weight.

\section{B. Ultimate Analysis}

The results of analyzed parameters Carbon, Hydrogen, Nitrogen, Sulphur and Oxygen are tabulated n Table-2. The results of each element are discussed below in detail.

Table-2: Descriptive statistics of Ultimate analysis of Yayu coals samples

\begin{tabular}{|l|c|c|c|c|c|}
\hline & $\mathrm{C}$ & $\mathrm{H}$ & $\mathrm{N}$ & $\mathrm{S}$ & $\mathrm{O}$ \\
\hline Minimum & 48.60 & 4.43 & 1.86 & 1.35 & 42.29 \\
\hline Maximum & 70.78 & 5.28 & 2.34 & 3.04 & 57.38 \\
\hline Mean & 63.54 & 4.96 & 2.00 & 1.88 & 51.90 \\
\hline Median & 66.36 & 5.07 & 1.97 & 1.79 & 52.26 \\
\hline stdev & 8.31 & 0.29 & 0.15 & 0.88 & 4.55 \\
\hline
\end{tabular}

\section{Carbon (C)}

The Carbon content in the collected coal samples from the study area varies from 48.60 to 70.68 wt\% with an arithmetic mean of $63.54 \mathrm{wt} \%$. The high concentrations of C are normally characteristic of vitrinite macerals [10,15]. It is also well known that the $\mathrm{C}$ content in coal increases steadily with increasing coal rank in Table 2 [10, 15, 16]. The measurement of $\mathrm{C}$ concentration in coal is still the leading and most accurate parameter among other chemical characteristics for evaluation of coal rank despite some limitations [8,10,13-17]. The carbon content of coal samples taken from the research area ranges from 48.60 to $70.68 \%$ by weight, with an arithmetic mean of $63.54 \%$ by weight. High concentrations of $\mathrm{C}$ are usually characteristic of vitrinite macerals $[10,15]$. It is also well known that the content of $\mathrm{C}$ in coal is steadily ncreasing with increasing coal rank in Tables 3. $[10,13,14]$. Measurement of C concentration in coal remains the main and most accurate parameter among other chemical characteristics for the assessment of coal rank [8, 10, 13-20].

Table -III: Variation of selected coal properties with coal rank [21]

\begin{tabular}{|c|c|c|c|c|c|}
\hline \multirow{4}{*}{$\begin{array}{l}\text { Rank: } \\
\text { Age: } \\
\text { \% Carbon: }\end{array}$} & <--------- & 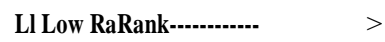 & $<---$ & High Rank-------- & \multirow{3}{*}{$\begin{array}{l}\text { Anthracite } \\
>\end{array}$} \\
\hline & Lignite & Sub-bituminous & \multirow{3}{*}{ Increase------ } & Bituminous & \\
\hline & 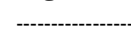 & & & & \\
\hline & $65-72$ & $72-76$ & & $76-90$ & $90-95$ \\
\hline \% Hydrogen: & 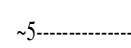 & & decreases---- & & $\sim 2$ \\
\hline \% Nitrogen: & $<+$ & & 1-2 --.---- & & $>$ \\
\hline \% Oxygen: & 30 & 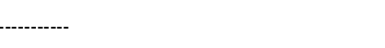 & decreases---- & & $\sim 1$ \\
\hline \% Sulphur: & > & increase---------- & 4 ------ & decreases------ & $\sim 0$ \\
\hline \% Water: & $70-30$ & $30-10$ & & 5 -Oct & $\sim 5$ \\
\hline Heating value & & & & & \\
\hline (BTU/lb) : & $\sim 7000$ & $\mid \sim 10,000$ & & $12,000-15,000$ & $\sim 15,000$ \\
\hline
\end{tabular}




\section{Oxygen (0)}

The oxygen content in the samples varies from 42.29 and $57.38 \%$ by weight with an arithmetic mean of $51.90 \%$ by weight. The higher $\mathrm{O}$ content is characteristic of low-range coals, while the decrease in concentration is typical of higher-range coals Table $3[8,14]$. The increase in $\mathrm{O}$ concentration is in accordance with higher moisture content and hydrated minerals.

\section{Hydrogen (H)}

The hydrogen content was found to range between 4.43 and $5.28 \%$ by weight with an arithmetic mean of $4.96 \%$ by weight. The higher $\mathrm{H}$ content is usually more characteristic for lower-range coals, while reduced values tend to be more typical for higher rank coals. Table 3. The concentrations of $\mathrm{H}$ increase with the increase in the degree of liptinite, alginate, resin, sporinite, cutinite and bituminization, as well as residual moisture, hydrated minerals and methane in coals $[13,16]$.

\section{Sulphur (S)}

The sulfur content of lignite samples is 1.35 to $3.04 \%$ by weight. With an arithmetic mean of 1.88 wt. The higher S content is more characteristic of lignite, while the reduced values of this element are more typical for higher order coals [18], with some exceptions in Table 3.

\section{Nitrogen $(\mathrm{N})$}

The nitrogen content in the coal samples in the studied area is from 1.86 to $2.34 \%$ by weight with an arithmetic mean of $2.00 \%$ by weight. The increased $\mathrm{N}$ content is usually more characteristic for higher-rank coals, while the reduced values of this element are usually more typical for lignite coals in Table 3.

\section{Gross Calorific value}

The thermal value is the amount of heat generated by burning a kilogram of coal and measured with a calorimeter. Gross calorific values of coal in the studied region differ from a minimum of $3943 \mathrm{Kcal} / \mathrm{Kg}$, and a maximum of $5839 \mathrm{Kcal}$ / Kg (on average $4916 \mathrm{Kcal} / \mathrm{Kg}$ ) given in Table 4.

Table 4: Gross Calorific values of the coal samples

\begin{tabular}{|c|c|c|}
\hline \multirow{2}{*}{ Minimum } & \multicolumn{2}{|c|}{ GCV } \\
\cline { 2 - 3 } & 3943 & 7092 \\
\hline Maximum & 5839 & 10503 \\
\hline Mean & 4916 & 8842 \\
\hline Median & 4922 & 8853 \\
\hline stdev & 763 & 1372 \\
\hline
\end{tabular}

The heat value determines the energy content of the fuel. It is a property of coal that depends on its chemical composition and moisture content [22] [23]. The most important property of fuel is its calorific value [24] [25]. Based on the analysis of laboratory results, in particular the percentage of coal and the amount of calorific value, it was established that the range of coal was from lignite to sub-bituminous coal and medium to high volatile [26].

\section{CONCLUSION}

The purpose of this study was to characterize coal in the study area by chemical composition using parameters in proximate and ultimate analyses. The moisture content in the coal are from 13.4 to $22.6 \%$ by weight, the fixed carbon content in the tested samples varies from 26.7 and 38\% by weight, the ash content in the samples differ from 11.9 up to $25.7 \%$ by weight, the volatile content of the samples is from 23.8 to $36.5 \%$ by weight. Gross calorific values of coal in the studied region are $4916 \mathrm{Kcal} / \mathrm{Kg}$ on average. Analytical results show that the carbon content is between 48.60 and $70.68 \%$ by weight, the oxygen content is between 42.29 and $57.38 \%$ by weight, the hydrogen content s between 4.43 and $5.28 \%$ by weight, sulfur content between 1.35 and $3.04 \%$ by weight, nitrogen content from 1.86 to $2.34 \%$ by weight. Proximate analysis and calorific value data show that Ethiopian coals are in the soft coal series (brown coal to bituminous coal) and are genetically classified as humic, sapropelic and mixed coal. In addition, proximate and ultimate analyses, when interpreted in detail, can be an effective tool for characterizing coal from any area. Knowing the geological history of the environment of the deposit area, the type of coal and chemical parameters are very mportant.

\section{REFERENCES}

1. S. Vassilev, C. Vassileva, "A new approach for the combined chemica and mineral classification of the inorganic in coal, Chemical and mineral classification systems", Fuel 88, 2009, 235-245.

2. Wolela Ahmed, "Fossil fuel energy resources of Ethiopia", bull. Chem. Soc. Ethiop. 22(1), 2008 67-84.

3. Mulata Haftu, Bheemalingeswara Konka, Kifle Woldeargay and Asmelash Abay, "Slope Stability Assessment and Underground Mine Design Analysis of Achibo-Sombo Underground Conventional Coal Mine, Southwest Ethiopia”, E3S Web of Conferences 1510040 , 2017.

4. N. Rao Cheepurupalli, Hagos Abraha and Mearg Belay, Artisanal gold mining challenges with special reference to mining and processing methods in Asgede Tsimbila and Lailay Adiyabo woredas, Northern Tigray, Ethiopia", ARPN Journal of Engineering and Applied Sciences, vol. 14, no.11, 2019, 2131-2138.

5. M. A. Rasheed, P. L. Srinivasa Rao, Annapurna Boruah, Syed Zaheer Hasan, Arpit Patel, Vaidik Velani, "Characterization of Coals Using Proximate and Ultimate Analysis of Western Coals, Gujarat, India", Geosciences, 5(4): 2015, 113-119.

6. A. Sahni, P.K. Saraswati, R.S. Rana, K. Kumar, H. Singh, H. Alimohammadian, N. Sahni, Kd, Rose, L. Singh, And T. Smith, "Temporal constraints and depositional palaeoenvironments of the Vastan lignite sequence, Gujarat: Analogy for the Cambay Shale hydrocarbon source rock." Indian Jour. Petrol. Geol., v.15, 2006 pp.1-20.

7. Shashi Chawla,"Theory and practicals of Engineering chemistry", Dhanpat Rai \& Co. 2011, Pp.426.

8. S. Vassilev, K., Kitano, C. Vassileva, “ Some relationships between coal rank and chemical and mineral composition”, Fuel 75, 1996, pp: 1537-1542.

9. S. Vassilev, J. Tascon, "Methods for characterization of inorganic and mineral matter in coal: a critical overview", Energy and Fuels 17, 2003, pp: 271-281.

10. E. Stach, M. Mackowsky, M. Teichmuller, G. Taylor, D. Chandra, R. Teichmuller, "Stach's Textbook of Coal Petrology", Gebruder Borntraeger, Berlin, 1982, pp: 535.

11. S. Vassilev, K. Kitano, C. Vassileva, Relations between ash yield and chemical and mineral composition of coals. Fuel 76, 1997, pp: 3-8.

12. R. Finkelman, "The inorganic geochemistry of coal: a scanning electron microscopy view", Scanning Microscopy 2, 1988, pp: 97-105.

13. G.D. Nicholls, "The geochemistry of coal-bearing strata", In Murchison, D., Westall, T. (Eds.), Coal and Coal bearing Strata. Oliver \& Boyd, 1968, pp: 269-307.

14. G. Eskenazy, "Ash distribution in coals from Maritza-East basin" Comptes Rendus de l'Academie Bulgare des Sciences 23,1970, pp: 1127-1130.

15. N. Berkowitz, “An Introduction to Coal Technology”, Academic Press Inc., London. 1979, pp. 345. 
16. Z. Li, C.R. Ward, L.W. Gurba, "Occurrence of non mineral inorganic elements in macerals of low-rank coals", International Journal of Coal Geology 81, 2010, pp: 242-250.

17. C.R. Ward, "Coal Geology and Coal Technology", Blackwell Scientific Publications, Melbourne, 1984, pp. 345.

18. W. Calkins, "The chemical forms of sulfur in coal: a review", Fuel 73, 1994, pp: 475-484.

19. N. Dobrogorskii, "Quality of Coal Ash and Its Utilization", Vichta Shkola, Kiev, 1981, 118 pp. (in Russian).

20. E. Williams, L. Keith, "Relationship between sulphur in coals and the occurrence of marine roof beds", Economic Geology, 58, 1963, pp 720-723. http://www.ems.psu.edu/ radovic/Chapter7.pdf.

21. "China National Complete Plant Import and Export Corporation LTD", Geological Report (Final) on Detailed Exploration of Wittete Minefield. Addis Abeba, 2007.

22. W. Tigist, "Coal Exploration Result in Ethiopia, Hydro carbon Exploration Team, GSE” (Unpublished report).EIGS, Addis Abeba, 2007.

23. Liu Guijian, Zheng Liugen, $\mathrm{Wu}$ Enjiang and Peng Zicheng, "Depositional and Chemical Characterization of Coal From Yayu Coal Field", Energy Exploration \& Exploitation, Volume 24, Number 6, 2006, pp. 417-438.

24. O. M., Aina, A. C. Adetogun, and K. A. Iyiola, "Heat Energy from Value-Added Sawdust Briquettes of Albizia Zygia”, Ethiopian Journal of Environmental Studies and Management Vol.2 No.1. 2009, pp 42-49.

25. H. Gebre Yohannes, "Geological report on coal deposit extension investigation around Wittete and Yayo blocks", (Unpublished report). EIGS, Addis Abeba , Vol. 1\&2, 2001.

\section{AUTHORS PROFILE}

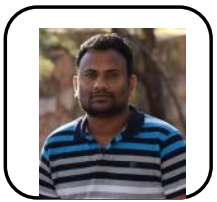

Dr. N. Rao Cheepurupalli, is working as an Assistant professor in the department of Mineral processing Engineering, School of mines at the Axum University, Ethiopia. He has more than 6 years of teaching experience in the field of Mining and Minera Processing Engineering. He is one of the Member of ESIA report for the establishment of Iron Ore Mining and Steel Making Plant at Indasillase, Tigray, Ethiopia. He has published more than 10 papers in national and international journals of repute. He has presented more than 8 papers at different places in the conferences and seminars.

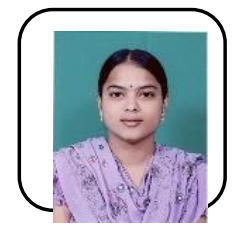

Dr. B. Anu Radha, Ph.D. in Geochemistry from Andhra University, Visakhapatnam, India. She is working as Chemist in Geological Survey of India (GSI), Hyderabad. She has received gold medal for presenting a best technical paper. She has published 6 papers in international Journals. She has presented 5 papers in both national and international symposia. 